\title{
Barriers to early detection of breast cancer among women in a Caribbean population
}

\author{
Naomi N. Modeste, ${ }^{1}$ Vonna Lou Caleb-Drayton, ${ }^{1}$ and \\ Suzanne Montgomery ${ }^{1}$
}

ABSTRACT The purpose of this descriptive study was to identify and describe barriers to early detection of breast cancer, as well as current breast cancer screening behaviors and attitudes regarding the disease, among women aged 20 and older on the Caribbean island of Tobago. Tobago is the smaller of the two islands that make up the nation of Trinidad and Tobago. Between February and June 1996, 265 women fitting the age criteria completed a structured survey questionnaire. Women of African descent made up 89\% of the respondents. In terms of age, $48 \%$ of those surveyed were between 20 and 39, 40\% were between 40 and 59 , and $12 \%$ were 60 or older. Barriers to early detection identified were a low level of breast self-examination, infrequent clinical breast examinations as part of regular care, unavailability of mammography services on Tobago, cost of screening, and difficulty of traveling to Trinidad for mammography. Furthermore, only a minority of the study participants had ever attended early detection or public awareness programs. The results were nearly the same for individuals with a family history of breast cancer, who would have a higher risk of occurrence of the disease. In addition, the majority of the respondents reported what can be considered a cultural barrier to early detection practices, a belief that no matter what they did, if they were to get breast cancer, they would get it. The authors recommend that mammography services be made available on Tobago. The authors also intend to use the findings to help develop an appropriate, culturally sensitive breast cancer awareness and early detection program for women on the island.

In developing countries and elsewhere around the world, the rising incidence of breast cancer and the increasing mortality from the disease are major health concerns. A primary reason for the escalating mortality is late diagnosis of the disease and a lack of early detection programs $(1,2)$. In the countries of the Caribbean, as in many other developing nations, a diagnosis of cancer is rightly feared since it often

\footnotetext{
1 Loma Linda University, School of Public Health, Loma Linda, California. Send correspondence to: Naomi N. Modeste, Loma Linda University, School of Public Health, Health Promotion and Education, Loma Linda, CA 92350. Phone: (909) 558-4575. Fax: (909) 558-4087. E-mail: nmodeste@ sph.llu.edu
}

comes in the late stages of the disease. In his book on cancer in Trinidad and Tobago, Dhanessar (3) indicated that since the most common symptom of breast cancer is a painless lump, women should be using breast selfexamination for early detection. When coupled with prevention education, early detection can reduce breast cancer mortality. The current guidelines from the American Cancer Society (4) state that women 20 years and older should practice monthly breast selfexamination (BSE). Women 20-39 years old should have a clinical breast examination (CBE) every three years, while women 40 years and older should have a yearly CBE. Women $40-49$ years old should also have a mammogram every 1-2 years, and women 50 years and older should have one yearly.

Other groups, however, have reached different conclusions about the usefulness and effectiveness of the various early detection methods. For instance, after reviewing the current evidence, the United States Preventive Services Task Force (5) concluded there was insufficient evidence to justify the cost of routine mammography and/or CBE for women between 40 and 49 and for those 70 years and older. The task force, however, did recommend routine breast cancer screening with mammography and/or CBE every 1-2 years for women 50-69. 
Thomas and Fick (6) reported that low-income women in Louisiana, a state in the southern part of the United States of America, were less likely to perform breast self-examination on a regular basis than were women in higher-income brackets, and physicians were less likely to recommend that these lower-income women participate in mammography screening. Many women do not undergo mammography because they do not know how mammography and other forms of breast cancer screening can contribute to early detection. Davis and colleagues (7) suggest that low income and limited literacy should be considered barriers to breast cancer prevention.

Research among black women in the United States indicated that although they had a lower incidence of breast cancer than white women did, cancer in blacks was usually more advanced when it was detected, and black women were likely to die sooner from the disease than white women were (8).

Mammography has been shown to play a vital part in early detection and improved survival rates among women. While recognized as one of the most effective screening procedures for early detection, this technique is also the most expensive. Because of this, efforts have been made, particularly in the United States, to make the procedure more affordable $(9,10)$.

Roughly half of the global breast cancer deaths occur in developing countries. Unfortunately, when mammography is available at all in these nations, it is not seen as a cost-effective option. Teaching BSE may help increase awareness and save lives, but women must begin the practice early in their lives $(11,12)$, and it should be coupled with CBE by a physician or other trained medical personnel.

Only limited information is available on breast cancer in the Caribbean. Results from a retrospective study (13) in Trinidad and Tobago indicated that breast cancer accounted for $17 \%$ of all cancers and $26 \%$ of those among women (compared to $31 \%$ of all cancers for women in the United States). Efforts have been made in recent years to improve the general reporting and monitoring of all cancers in the Caribbean. For instance, the Cancer Centre, which is located on Trinidad and serves Trinidad and Tobago and other Caribbean territories, was organizing a national cancer registry at the time of this survey, in 1996.

This paper aims to add to the knowledge base by identifying and describing barriers to early detection of breast cancer among women living on the island of Tobago, who must travel to the larger, sister island of Trinidad for mammography services. The authors will also review information that might be useful in developing an appropriate, culturally sensitive breast cancer program to inform women about the importance of early detection and to improve screening and referral.

\section{METHODOLOGY}

\section{Study population}

Our study population consisted of 265 women 20 years and older living on the island of Tobago who volunteered for the study. A convenience sample was selected from among women attending community health centers, businesses, work sites, and churches. Every effort was made to interview women from different socioeconomic and educational levels and from both rural and city areas so as to produce a mixture of characteristics within the survey population.

Since this was a population-based convenience sample, we needed a power that would detect differences of opinion between groups of people. Assumptions for the power were based on the attitudes of women who do BSE and on those who do not. Applying Cohen (14), the power analyses indicated that a sample size of 250 would be sufficient.

\section{Data collection}

A structured questionnaire was developed, pretested, and used to collect data. The questionnaire included ques- tions to determine the respondents' perceived barriers to early detection, as well as their knowledge and use of early detection methods. Also included were sections on attitudes, beliefs, family history of breast cancer, sources of information about breast cancer, reproductive history, and such demographic characteristics as age, marital status, education, occupation, average monthly household income, and religion.

The questionnaire was self-administered to women fitting the age criteria who agreed to participate in the study. For confidentiality, participants were instructed not to write their names on the questionnaire. Those assisting with the data collection retrieved the completed questionnaires and placed them in envelopes that were sealed until time for data entry.

\section{Data analysis}

The data was entered and analyzed using SPSS 7.5 statistical software (SPSS Inc., Chicago, IL). After checking the data for missing values and outliers, descriptive statistics were generated for all variables. Frequencies, percentages, and modes were calculated on categorical variables; means, medians, and standard deviations were determined for continuous variables. In addition, descriptive statistics were derived for variables measuring the screening behaviors of respondents with a family history of breast cancer.

All variables measuring the respondents' perceptions of barriers to early detection of breast cancer-unavailability of programs, cost of screening, fear of cancer, access (transportation) to care, waiting time for screening, inconvenience of screening, and the unpleasant nature of the examination-were cross-tabulated with age, education, marital status, income, and occupation. Cross-tabulations with these demographic variables were also done with variables measuring the level of difficulty of traveling to Trinidad for a mammogram and with variables used to identify this society's cultural barrier to early detection. 


\section{RESULTS}

\section{Demographics}

Questionnaires were completed by 265 women 20 years and older living on the island of Tobago. Of the respondents who indicated their age, $25 \%$ were between 20 and $29,23 \%$ between
30 and $39,21 \%$ between 40 and 49 , $19 \%$ between 50 and 59 , and $12 \%, 60$ or older. Thus, according to the American Cancer Society guidelines, the $52 \%$ of the women age 40 and older would have benefited from regular mammography screening. Table 1 provides additional details on the questionnaire respondents.

TABLE 1. Characteristics of women surveyed $(n=265)$ concerning early detection of breast cancer, Tobago, February-June 1996

\begin{tabular}{|c|c|c|c|}
\hline Variable & Categories & Number & Percent \\
\hline Age & $\begin{array}{l}20-29 \\
30-39 \\
40-49 \\
50-59 \\
\geq 60\end{array}$ & $\begin{array}{l}62 \\
56 \\
51 \\
47 \\
30\end{array}$ & $\begin{array}{l}25.2 \\
22.8 \\
20.7 \\
19.1 \\
12.2\end{array}$ \\
\hline Ethnicity & $\begin{array}{l}\text { African descent } \\
\text { Mixed } \\
\text { Indian descent } \\
\text { Caucasian } \\
\text { Other }\end{array}$ & $\begin{array}{r}214 \\
8 \\
3 \\
16 \\
1\end{array}$ & $\begin{array}{r}89.0 \\
3.3 \\
1.2 \\
6.6 \\
0.4\end{array}$ \\
\hline Education & $\begin{array}{l}\text { Primary } \\
\text { Vocational } \\
\text { Secondary } \\
\text { Post-secondary } \\
\text { College/university } \\
\text { Other }\end{array}$ & $\begin{array}{r}63 \\
17 \\
115 \\
18 \\
26 \\
1\end{array}$ & $\begin{array}{r}26.3 \\
7.1 \\
47.9 \\
7.5 \\
10.8 \\
0.4\end{array}$ \\
\hline $\begin{array}{l}\text { Monthly household income } \\
\left(\text { TT\$ } \$^{a}\right)\end{array}$ & $\begin{array}{l}<\$ 1000 \\
\$ 1000-\$ 2000 \\
\$ 3000-\$ 5000 \\
>\$ 5000\end{array}$ & $\begin{array}{l}53 \\
75 \\
69 \\
39\end{array}$ & $\begin{array}{l}22.5 \\
31.8 \\
29.2 \\
16.5\end{array}$ \\
\hline Marital status & $\begin{array}{l}\text { Single } \\
\text { Married } \\
\text { Widowed } \\
\text { Divorced } \\
\text { Separated } \\
\text { Other }\end{array}$ & $\begin{array}{r}102 \\
124 \\
15 \\
6 \\
9 \\
6\end{array}$ & $\begin{array}{r}38.9 \\
47.3 \\
5.7 \\
2.3 \\
3.4 \\
2.3\end{array}$ \\
\hline No. of children & $\begin{array}{l}\text { None } \\
1-3 \\
4-6 \\
\geq 7\end{array}$ & $\begin{array}{r}71 \\
112 \\
57 \\
16\end{array}$ & $\begin{array}{r}27.7 \\
43.8 \\
22.3 \\
6.3\end{array}$ \\
\hline Religion & $\begin{array}{l}\text { Protestant } \\
\text { Roman Catholic } \\
\text { Non-Christian }\end{array}$ & $\begin{array}{r}198 \\
20 \\
16\end{array}$ & $\begin{array}{r}85.0 \\
9.0 \\
6.0\end{array}$ \\
\hline Employment & $\begin{array}{l}\text { Professional } \\
\text { Public servant } \\
\text { Retired } \\
\text { Housewife } \\
\text { Laborer } \\
\text { Self-employed } \\
\text { Unemployed } \\
\text { Other }\end{array}$ & $\begin{array}{r}39 \\
52 \\
9 \\
72 \\
7 \\
17 \\
5 \\
33\end{array}$ & $\begin{array}{r}16.7 \\
22.2 \\
3.8 \\
30.8 \\
3.0 \\
7.3 \\
2.1 \\
14.1\end{array}$ \\
\hline
\end{tabular}

${ }^{a}$ Exchange rate at the time of the study was TT $\$ 6.20$ per US $\$ 1.00$.

\section{Barriers to early detection}

To determine what the Tobagonian women perceived as barriers to early detection of breast cancer, the questionnaire asked them to select as many items as applied from a list of seven suggested possibilities. The most important barriers cited were the unavailability of programs for early detection ( $66 \%$ of respondents), cost of screening $(52 \%)$, and fear of cancer $(48 \%)$. The other barriers that the women mentioned were access to care (having to travel to Trinidad for a mammogram) $(34 \%)$, the time involved in waiting for screening $(22 \%)$, the inconvenience of screening (such as having to take time off from work or to arrange care for children left at home) $(15 \%)$, and the fact that the clinical breast examination was unpleasant $(7 \%)$.

At the time of the study, the cost for ground and air transportation to go to Trinidad for mammography services was around TT\$ 400 (the exchange rate at that point was TT\$ 6.20 per US\$1.00). That travel expense would be in addition to the fees for a mammogram and other services. When asked about making such a trip, $66 \%$ of the respondents indicated it would be very difficult or somewhat difficult, $17 \%$ felt it would not be difficult, $14 \%$ were not sure, $2 \%$ said that they would not go there for a mammogram, and $1 \%$ did not answer the question.

Regardless of age, education, marital status, income, and occupation, the majority of respondents said they believed that no matter what they did, if they were to get breast cancer, they would get it. This can be considered a cultural barrier to early detection.

\section{Breast cancer awareness/information}

When asked whether or not mammogram screening was available on their island, $67 \%$ of the Tobagonian women correctly indicated that it was unavailable, $30 \%$ did not know, and 2\% mistakenly thought it was available. 
Furthermore, $92 \%$ of the participants indicated they had never attended a breast cancer awareness program.

In order to find out where women received information about cancer, they were given a list of possible sources and were asked to check as many as applied. The most important sources mentioned were television (63\% of the respondents), newspapers $(46 \%)$, flyers from health centers $(42 \%)$, and the radio $(41 \%)$. Other sources included nurses $(22 \%)$, physicians $(22 \%)$, friends $(16 \%)$, and relatives $(12 \%)$. Five percent of the women said that they had not received any information about breast cancer.

\section{Screening behaviors}

Sixty percent of women participating in the study said they had been taught how to examine their breasts for lumps. However, only $31 \%$ of the respondents indicated they had performed the exam within the preceding month, and only $37 \%$ reported that they examined their breasts more than twice per year. Further, only $23 \%$ of the women reported that a clinical breast examination was routinely included as part of their visit to a doctor.

\section{Family history}

When asked if anyone in their family had ever had breast cancer, $13 \%$ of the respondents answered affirmatively. The family members they listed most often as having had the disease were cousins, followed by mothers, sisters, and aunts. Only one survey participant herself had had breast cancer, and one had a daughter with the disease. None of the women with a family history of breast cancer had ever attended a breast cancer awareness program. Although $70 \%$ of the women in this group said they had been taught how to examine their breasts for lumps, only 39\% did so on a monthly basis, and $61 \%$ did the procedure just once per year. For $70 \%$ of these respondents, clinical breast ex- amination was not a routine part of their visit to the doctor.

\section{DISCUSSION}

The main limitations of this study were that the survey was conducted on one Caribbean island with a population of approximately 46000 residents and that probability statistics were not employed. Specific demographic data on population distributions by age and income were not available separately for Tobago, and so comparisons cannot be made with the entire population of the island. We recognize these limitations and the potential bias of the study design and can only claim applicability of findings to the women surveyed. Nevertheless, we strongly believe that these findings and recommendations on Tobagonian women may be applicable for program development and implementation on other, similar Caribbean islands where mammography services are unavailable.

The barriers to early detection that the Tobagonian women identified reveal a definite need for mammography services on the island, particularly for all women within the age groups designated by the American Cancer Society. We recognize that with such a small population, maintaining a machine and technical personnel on the island may not be costeffective. It is important, therefore, to look for appropriate alternatives for the island, such as subsidizing the cost of obtaining mammography services on Trinidad.

Since mammography screening is not available on Tobago and only a small percent of participants can easily obtain this service on Trinidad, there is a need to focus on such screening programs as breast self-examination and clinical breast examination. If there is health education regarding the importance of the screening programs, including awareness of better survival rates when breast cancer is detected early and treated promptly, a higher percentage of women may learn and practice BSE. They also may make sure that a CBE is included as a part of their regular physical examination.

Training is needed for nurses, doctors, and other health professionals. They in turn will teach women how to examine their breasts for lumps and take advantage of mammography screening when available. Some of the survey participants said that they had learned to examine their breasts from television. A more realistic practice using models designed with lumps in them and coupled with health education information would certainly be an asset.

The study showed that only $39 \%$ of Tobagonian women with a family history of breast cancer were performing BSE on a monthly basis. This indicates they may be quite unaware of the relationship between a family history of breast cancer and the development of the disease. These findings are similar to ones from Drossaert and colleagues (15), who reported they did not detect any difference in behaviors for early detection among women who knew their family history and women who did not know that history. We believe that on Tobago this higher-risk population should be made aware that the risk of breast cancer increases if other family members have had the disease and that the closer the family member, the more empowered they should be to engage in protective behaviors.

The Tobagonian respondents reported they most frequently obtained information on breast cancer from television and newspapers, and there is a need to expand on that information base and educate more women about the importance of early detection. For instance, more articles in the newspapers, as well as seminars and workshops in local communities, about cancer in general and breast cancer in particular, could enhance knowledge.

On Tobago and with other, similar populations, health education focusing on breast health awareness and early detection may help change negative beliefs and attitudes about the disease and empower women to participate more actively in making important decisions regarding their health. 


\section{REFERENCES}

1. Pinotti JA, Barros AC, Hegg R, Zeferino LC. Breast cancer control program in developing countries. Breast Disease 1995;8:243-250.

2. Parkin DM. Cancer in developing countries. Cancer Surv 1994;19-20:519-561.

3. Dhanessar W. Rays of Hope. Port of Spain, Trinidad: Imprint Caribbean Ltd.; 1980.

4. American Cancer Society. Breast self-examination: a new approach [pamphlet]. [City unknown], California: ACS; 1996. (Publication 6438.39).

5. U.S. Preventive Services Task Force. Guide to clinical preventive services. Alexandria, Virginia: International Medical Publishing, Inc.; 1996.

6. Thomas SM, Fick AC. Women's health: early detection and screening practices for breast and cervical cancer. J La State Med Soc 1994; 146:152-158.

7. Davis TC, Arnold C, Berkel HJ, Nandy I, Jackson $\mathrm{RH}$, Glass J. Knowledge and attitude on screen- ing mammography among low-literate, lowincome women. Cancer 1996;78(9):1912-1920.

8. Moormeier J. Breast cancer in black women Ann Intern Med 1996;124(10):897-905.

9. Parker CB, Simpson J, McCooey LS. A mammogram coupon program: a collaborative effort to provide mammograms to uninsured women in Connecticut. Conn Med 1995; 59(8):451-454.

10. Earp JA, Altpeter M, Mayne L, Viadro CI, O'Malley MS. The North Carolina breast screening program: foundations and design of a model for reaching older minority rural women. Breast Cancer Res Treat 1995;35 (1):7-22.

11. Ludwick R, Rushing B, Luskin Biordi D. Breast cancer and the older woman: information and images. Health Care Women Int 1994;15(3):235-242.

12. Lee Champion V. Relationship of age to factors influencing breast cancer examination practice. Health Care Women Int 1992;13(1): $1-9$.

13. Raju GC, Naraynsingh V. Breast cancer in West Indian women in Trinidad. Trop Geogr Med 1989;41(3):257-260.

14. Cohen J. Statistical power analysis for the behavioral sciences. 2nd ed. Hillsdale, NJ: Lawrence Erlbaum Assoc.; 1988.

15. Drossaert CC, Boer H, Seydel ER. Perceived risk, anxiety, mammogram uptake, and breast self-examination of women with a family history of breast cancer: the role of knowing to be at increased risk. Cancer Detect Prev 1996; 20(1):76-85.

Manuscript received on 18 December 1997. Revised version accepted for publication on 2 February 1999.

RESUMEN Este estudio descriptivo tuvo como objetivo reconocer y describir las barreras que dificultan la detección temprana del cáncer de mama, el comportamiento en torno al tamizaje y las actitudes hacia ese tipo de cáncer en mujeres de 20 o más años de edad de la isla caribeña de Tabago. Esta es la más pequeña de las dos islas que constituyen la nación de Trinidad y Tabago. Entre febrero y junio de 1996, 265 mujeres que cumplían con el criterio de la edad llenaron un cuestionario de encuesta estructurado. Eran de descendencia africana $89 \%$ de las que respondieron. En cuanto a edad, $48 \%$ de las encuestadas tenían entre 20 y 39 años, $40 \%$ tenían entre 40 y 59, y 12\% tenían 60 o más. Las barreras que reconocieron frente a la detección temprana fueron la poca costumbre de autoexaminarse el seno, la escasa frecuencia de exámenes del seno en la atención de salud habitualmente recibida, la falta de servicios de mamografía en Tabago, el costo del tamizaje y la dificultad de tener que viajar a Trinidad para hacerse una mamografía. Además, solo una pequeña proporción de las participantes en el estudio había jamás asistido a algún programa de detección temprana o concienciación del público. Los resultados fueron casi idénticos en las que tenían antecedentes familiares de cáncer y, por lo tanto, mayor riesgo de la enfermedad. Por añadidura, la mayoría de las que respondieron a la encuesta dejaron traslucir lo que podría interpretarse como una barrera cultural contra la práctica de detección temprana, o sea, la creencia de que si estaban destinadas a tener cáncer de mama, lo tendrían hicieran lo que hicieran. Los autores recomiendan que en Tabago se hagan asequibles al público los servicios de mamografía. También piensan usar los resultados del estudio para elaborar un programa apropiado y culturalmente sensible de concienciación sobre el cáncer de mama y su detección temprana en la isla. 